Леонид Михайлович Рапопорт, доктор медицинских наук, профессор, кафедра урологии, Первый МГМУ им. И. М. Сеченова, ул. Большая Пироговская, 2, г. Москва, Россия, 119991

Вагаршак Арамаисович Григорян, доктор медицинских наук, профессор, кафедра урологии, Первый МГМУ им. И. М. Сеченова, ул. Большая Пироговская, 2, г. Москва, Россия, 119991

Евгений Алексеевич Безруков, доктор медицинских наук, профессор, кафедра урологии, Первый МГМУ им. И. М. Сеченова, ул. Большая Пироговская, 2, г. Москва, Россия, 119991

Денис Викторович Бутнару, кандидат медицинских наук, доцент, кафедра урологии, Первый МГМУ им. И. М. Сеченова, ул. Большая Пироговская, 2, г. Москва, Россия, 119991

Лилия Саидовна Демидко, врач, клиника урологии, Первый МГМУ им. И. М. Сеченова, ул. Большая Пироговская, 2, г. Москва, Россия, 119991

Сергей Алексеевич Мянник, аспирант, НИИ уронефрологии и репродуктивного здоровья человека, ул. Большая Пироговская, 2, г. Москва, Россия, 119991

Тимур Барабекович Соблиров, научный сотрудник, отдел функциональной диагностики и методов лечения, НИИ уронефрологии и репродуктивного здоровья человека, ул. Большая Пироговская, 2, г. Москва, Россия, 119991

УДК: 616.8-056.7 - 036.22

DOI: 10.15587/2313-8416.2015.38184

\title{
ПОПУЛЯЦИОННО-ЭПИДЕМИОЛОГИЧЕСКИЕ АСПЕКТЫ НАСЛЕДСТВЕННЫХ БОЛЕЗНЕЙ НЕРВНОЙ СИСТЕМЫ
}

\author{
(C) И. А. Говбах \\ В статье представлены данные по распространенности наследственных заболеваний нервной систе- \\ мы в наиболее изученых популяциях мира; охарактеризованы процессы формирования генетической мо- \\ дели популяций. Дано описание украинской популяции с учетом особенностей микроэволючионных про- \\ иессов; рассмотрены морфологические основы антролопологического типа украинцев. Представлены \\ исторические этапы образования и современные особенности одного из этно-территориальных ареалов \\ украицев - Слобожанщины \\ Ключевые слова: наследственные болезни нервной системы, эпидемиология, генетический груз, украин- \\ ская популяиия, Слобожанщина
}

Aim. One of the basic approaches to the personalized medicine, predictive, carrying out the disease foresight before its symptomatic display is presented in the paper. Within the framework of the predictive approach, the study of diseases frequency and prevalence in populations is taking on significance.

Methods. The data of hereditary neurological disorders prevalence in most studied world populations are given in the paper; the forming mechanisms of population genetic load and its change in generations have been considered. The basic evolutional processes of populations genetic model forming and importance of such factors as migrations and mutations have been considered. The description of Ukrainian population from its formation as ethnos up to the present taking into account microevolutionary process features has been given.

Result. The Ukrainian anthropological type and morphological bases of its forming have been considered. The historical stages of formation and modern features of Slobozhanshchyna, one of the Ukrainian ethnoterritorial areas have been presented. According to statistics data on 01.01.2014, the population of Slobozhanshchyna is 5 million 328 thousand people, that is 12,5\% of the population of Ukraine; by a degree mono- and polyethnicity Slobozhanshchyna relates to a mixed zone with Ukrainian population predominance (from $70 \%$ to $83 \%$ ) and significant portion of Russians (up to $20 \%$ ); Slobozhanshchyna is the highly urbanized part of Ukraine and the most industrially and economically developed region, that forms ecological features connected with the industrialization of the region as well as a high degree of migration flows.

Conclusions. The features of Slobozhanshchyna cause the necessity of population studies of hereditary neurological disorders frequency and prevalence in the region in order to develop methods of early diagnostics and prevention that are the most optimal for Slobozhanshchyna

Keywords: hereditary diseases of nervous system, epidemiology, genetic load, Ukrainian population, Slobozhanshchyna 


\section{1. Введение}

Здоровье населения занимает одно из первых мест в системе жизненных ценностей любого государства. Снижение заболеваемости и сохранение здоровья населения - важнейшие социально-экономические задачи страны и особо остро они стоят сегодня перед Украиной, поскольку такие факторы настоящего времени как снижение численности населения наряду с высокой заболеваемостью и смертностью являются реальной угрозой не только развития страны, но и ее национальной безопасности.

Благодаря прогрессу в развитии общества и медицины, в конце 90-х годов XX века сформировалась концепция геномной или персонифицированной медицины, в основе которой лежат принципы классиков отчественной медицины XIX века. Принцип персонального подхода к больному получил новое прочтение в XXI веке в виде основного постулата персонифицированной медицины: «рутинное использование генотипического анализа, обычно в форме ДКН-тестирования, с целью улучшения качества медицинской помощи». Новые подходы позволяют перейти от существующей сегодня медицины «реагирования», которая имеет дело с уже существующей болезнью и борется с симптомами, к персонифицированной или геномной медицине. Лерой Худ, лаурет Нобелевской премии и один из основоположников персонифицированной медицины, определяет ее как медицину четырех «П»: предиктивную (направленную на предсказание болезни до ее симптоматического появления); превентивную (предупреждающую болезнь); персонифицированную (учитывающую индивидуальные, прежде всего, генетические особенности пациента) и партсипаторную (медицину участия, т. е. подразумевающую активное участие пациента в выявлении его генетических особенностей и превентивных мерах) [1, 2].

\section{2. Анализ литературных данных и поста- новка проблемы}

Реализация таких проектов как «Геном человека», «Геномы рас», «1000 и 1 геном», «GWAS» (Genome-Wide Association Study), позволила накопить огромное количество информации о моногенных наследственных болезнях (НБ), мультифакториальных (полигенных) заболеваний и различных генетически обусловленных предрасположенностях. На основе исследований по изучению генома человека удалось идентифицировать не только гены, вызывающие моногенные НБ, но и мутации, которые приводят к наиболее частым, т. н. мультифакториальным заболеваниям, являющихся результатом взаимодействия генетических факторов и неблагоприятных условий внешней среды. Доказано, что этиопатогенетической основой таких мультифакториальных заболеваний как эссенциальная гипертония, сахарный диабет, бронхиальная астма, атеросклероз, некоторые формы рака является генетический фактор, а именно наличие т. н. «генов предрасположенности», повреждающий эффект которых реализуется на фоне действия неблагоприятных факторов внешней среды [3-5].
И если для мультифакторных заболеваний генетические изменения не единственно определяющие развитие болезни, то для моногенных НБ являются этиологической причиной. С учетом отсутствия на сегодняшний день патогенетических методов лечения большинства форм НБ наиболее эффективным методом борьбы с данной патологией является не столько профилактика, но прежде всего предвидение возникновения заболевания. Слова французского ученого Жана Доссе, основателя предиктивной медицины, лауреата Нобелевской премии: «чтобы предупредить болезнь, ее нужно предвидеть», сейчас актуальны как никогда [6].

В структуре моногенных НБ значительную часть составляют наследственные болезни нервной системы (НБНС). На их долю приходится существенная часть, более 5 \%, всей неврологической патологии в современном обществе. НБНС занимают особое место как в ряду всех форм наследственных заболеваний человека, так и патологии нервной системы, что связано с их общей высокой распространенностью, большим разнообразием нозологических единиц, значительным фенотипическим полиморфизмом и выраженной генетической гетерогенностью. Большинство НБНС носят тяжелый прогрессирующий характер, часто приводят к ранней инвалидизации, а иногда и смерти больного, при этом на сегодняшний день эффективное патогенетическое лечение не разработано $[4,7,8]$.

Индивидуальный подход, как основой принцип персонифицированной медицины, обусловлен частично и наличием выраженного клинического полиморфизма многих заболеваний, проявляющийся в развитии у отдельных индивидуумов различной степени патологических проявлений от стертых до тяжелых форм.

Развитие НБ происходит в результате воздействия этиологического фактора в виде строго детерминированных генных мутаций, прошедших в ходе эволюции десятков и сотен лет естественный отбор с помощью приобретения определенного типа наследования и молекулярно-генетических особенностей, а также четкого механизма патогенеза, полностью контролируемого генной активностью. В связи с этим, можно было бы предполагать наличие строго унифицированных клинических проявлений в пределах определенной нозологической формы. Однако, многие НБНС являются клинически и генетически гетерогенными с широкой вариабельностью возраста манифестации заболевания, его длительности и сроков продолжительности жизни, полноте и тяжести клинических проявлений, а также глубине патологического процесса. Клинический полиморфизм НБНМ значительно затрудняет их дифференциальную диагностику и, соответственно, предупреждение их возможного развития в популяции $[3,4,9]$.

Впервые клинический полиморфизм НБНС начал глубоко анализировать еще в 20-30-х годах XIX века выдающий невропатолог и генетик С. Н. Давиденков, доказавший, что его основными причинами явля- 
ются окружающая среда, характер мутаций и специфические генотипические особенности популяции; им также была выявлена генетическая гетерогенность, проявляющееся в возникновении различных генокопий заболевания и маскирующаяся под клинический полиморфизм. Дальнейшие исследования показали, что патогенез любого наследственного заболевания происходит по единой схеме и связан с реализацией генного кода от локуса в хромосоме до признака согласно закону Бидла-Татума: ген $\rightarrow$ фермент $\rightarrow$ обмен $\rightarrow$ вещество $\rightarrow$ признак. Известно, что определенные генные локусы активно функционируют в различные периоды жизни, что по-видимому, может влиять на время манифестации НБ, а индивидуальные особенности функционирования ферментных систем, биохимических и обменных процессов могут оказывать влияние на клинические проявления $[10,11]$.

Однако, несмотря на достаточно широкий клинический полиморфизм, характерным для всех НБ является отсутствие плавного перехода от нормы к патологии и даже легкие формы болезни имеют хотя весьма и минимальные, но значимые для данного заболевания диагностические признаки, что соответствует основному генетическому правилу: нормальный генотип детерминирует нормальный фенотип, а мутантный генотип детерминирует мутантный фенотип $[8,12]$.

Большое медико-социальное и экономическое значение, учитывая выше указанное, приобретают ранняя диагностика и предупреждение НБНС, полноценное проведение которых невозможно без представления об этиологии, патогенезе и особенностях их распространения.

\section{3. Популяционно-эпидемиологические} аспекты наследственных болезней нервной системы

Значительный приоритет в настоящее время приобретают исследования, позволяющие оценить популяционную частоту наследственной патологии и изучить их клинический полиморфизм и генетическую гетерогенность. Эпидемиологии отдельных НБ в разных популяциях посвящены многие публикации как отечественных, так и зарубежных авторов, свидетельствующие о том, что не существуют НБ, имеющих одинаковую популяционную частоту встречаемости и спектр мутаций генов, детерминирующих их развитие. Исследование эпидемиологических особенностей НБНС в различных популяциях проводились как во всем мире, так и на территории стран бывшего Советсткого Союза (табл. 1). Наиболее масштабные работы были проведены у исландцев, финнов, арабов, японцев, евреев ашкенази. Среди государств бывшего СССР к наиболее изученным популяциям следует отнести башкир, азербайджанцев, узбеков, туркмен и отдельные этно-географические подгруппы славян (на примере ряда географических регионов России) [13-16].
Таблица 1

Распространенность НБНС в ряде изученных популяций мира

\begin{tabular}{|c|c|c|}
\hline \multicolumn{2}{|r|}{ Регион (популяция) } & $\begin{array}{c}\text { Распространенность } \\
\text { наследственных } \\
\text { болезней нервной } \\
\text { системы (на } 100 \text { тыс. } \\
\text { населения) }\end{array}$ \\
\hline \multicolumn{2}{|r|}{ США (средние данные) } & 20,0 \\
\hline \multicolumn{2}{|r|}{ Япония } & $15,5-28,5$ \\
\hline \multicolumn{2}{|r|}{ Норвегия } & 24,9 \\
\hline \multicolumn{2}{|r|}{ Франция } & $19,7-25,0$ \\
\hline \multirow{6}{*}{ 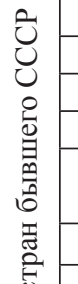 } & Азербайджан & 10,4 \\
\hline & Архангельская область & 7,2 \\
\hline & Амурская область & 14,8 \\
\hline & Владимирская область & 21,9 \\
\hline & $\begin{array}{c}\text { Донецкая область } \\
\text { (детская популяция) }\end{array}$ & 12,0 \\
\hline & Кировская область & $14,8-39,1$ \\
\hline \multirow{6}{*}{ 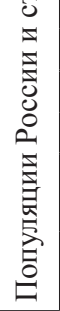 } & Костромская область & 16,5 \\
\hline & Краснодарский край & 24,7 \\
\hline & Самарская область & $11,0-12,0$ \\
\hline & Саратовская область & $11,0-12,0$ \\
\hline & $\begin{array}{c}\text { Туркмения } \\
\text { (Ахалский велаят) } \\
\end{array}$ & $20,0-25,0$ \\
\hline & $\begin{array}{c}\text { Узбекистан (Самаркандская } \\
\text { и Хорезмская области) }\end{array}$ & 19,3 \\
\hline
\end{tabular}

Изучение распространенности НБНС важно как с теоретической, так и с практической точек зрения. Теоретическое значение заключается в определении модели генетической структуры популяции с учетом территориального распределения мутантных генов и особенностей генетической дифференциации популяции, а также генетического груза популяции, который определяется как снижение средней приспособленности популяции по сравнению с популяцией, все индивидуумы котрой обладают генотипом, обеспечивающим максимальную приспособленность. С практической точки зрения выявление популяционно-территориальных особенностей распространения, спектра, вариабельности проявлений и генетической природы наследственной патологии является основой для создания эфективной системы их мониторинга, а также разработки методов диагностики и профилактики, оптимальных для конкретного региона [17-20].

В литературе весьма интенсивно обсуждаются возможные причины межпопуляционных различий в распространенности тех или иных форм наследственных болезней нервной системы, первостепенными из которых являются молекулярно-генетические особенности, свойственные конкретным популяциям. Согласно современной теории эволюции основными факторами, определяющими формирование генофонм да различных популяций, являются естественный отбор, миграции, мутации и случайные события. В результате их суммарного воздействия в конкретных условиях среды происходит интеграция уникальных особенностей структуры определенных групп, проявляющаяся в виде дифференциации разных популяций в пространстве признаков. 
Динамика современных микроэволюционных процессов достаточно сложна и неоднозначна, и, в целом, значительно отличается от таковой в малых изолированных популяциях прошлого. Последние десятилетия характеризуются ростом урбанизации; значительным увеличением масштабов миграций и, как следствие, расширением границ брачных ареалов, ростом доли межнациональных браков и связанной с этим рекомбинацией генов, что в совокупности создает предпосылки для образования новых генотипов и значительного роста уровня генетической изменчивости. Учитывая также, что наряду с перечисленными факторами, одновременно происходит значительное снижение роли естественного отбора и влияние большого количества мутагенных факторов, можно предполагать, что генетический груз в популяциях человека увеличивается. Об этом еще 1950-х годах говорил основоположник популяционной генетики Г. Меллер: «Многие генотипы, которые имели сниженную приспособленность и отбраковывались путем естественного отбора, в современном обществе доживают до репродуктивного возраста и оставляют потомство также со сниженной приспособленностью; в результате генетический груз растет, а приспособленность современных популяций падает, что может иметь драматические последствия для всего человечества...» [4, 21-24].

Следует также отметить, что дифференциация в отягощенности и разнообразии НБ выявлена не только между разными популяциями, но и среди отдельных групп одного вида популяции, проживающих в различних климато-географических и экологических зонах. Следовательно, результаты, полученные при исследовании одного локального этно-территориального региона, нельзя переносить на всю популяцию в целом, в связи с чем исследование закономерностей формирования структуры и динамики генетических особенностей популяции отдельных регионов является актуальным, научно обоснованым и логичным $[15,23]$.

Эпидемиологические исследования НБНС в украинской популяции представляют «белое пятно» в изучении данной патологии, что обусловливает актуальность их проведения. Украинская популяция характеризуется значительным своеобразием генофонда ее населения, формирование которого имеет длительную и сложную историю. Из всех восточнославянских народов (русские, белорусы, украинцы), именно украинцы находятся ближе всего к области пересечения ареалов восточных, западных и южных славян. Многие раннесредневековые и даже более древние культуры, связываемые этнологами с древними славянами, обнаружены на территории современной Украины. По словам ученого-антрополога В.Д. Баран, исследовавшего популяцию славян: «украинцы - один из древних народов, зародившихся в недрах восточно-славянской этнической общности» $[25,26]$.

Формирование украинцев как этноса, согласно наиболее принятой точки зрения, началось в период феодальной раздробленности Древнерусского государства (XII-XIII вв.), а завершилось в XIV-XV вв. Начиная с XV в. разные части территории современной Украины входили в состав соседних государств:
Речи Посполитой, Османской Империии (Правобережье), Московского Царства (Левобережье); а с конца XVIII в. - в состав Российской и Австрийской Империи. Нынешние территориальные границы современного государства Украина существуют с 1939 г. [27].

Согласно антропологической классификации выделяют основные группы славянской популяции, образующие компактные ареалы: беломоро-балтийский, днепро-карпатский, понтийский и динарский. Украинцы принадлежат к днепро-карпатской группе популяции славян, куда также входят прикарпатские этнографические группы, словаки, частично чехи, сербы, хорваты, а также южные, центральные и восточные венгры. Антропологический тип украинской популяции является самостоятельным, исторически сформированным, отличительные признаки которого обнаруживаются на территории современной Украины уже в эпоху средневековья. Морфологической основой для формирования специфических черт антрополологического типа украинской популяции явились восточнославянские племена полян, древлян, волынян, северян, уличей, тиверцев, угров [25-28].

Важной особенностью украинской популяции является большое антропологическое и культурно-этнографическое разнообразие локальных территориально-этнических районов, связанное со сложным историческим процессом их формирования в процессе заселения ареала украинской популяции, которая с древнейших времен располагалась на пересечении леса и лесостепи Восточной Европы, Евразийских степей и Балкано-Карпатского исторического региона. Выделяют основные территориальные историко-этнографическими районы украинцев: Среднее Поднепровье, Подолье, Галиция, Запорожье, Слобожанщина, Полесье, Закарпатье, Буковина, Покутье, Таврия, Донбасс, Южная Бессарабия [25, 27, 29].

На рис. 1 представлены основные историко-этнографические территориальные подразделения украинцев.

Слобожанщина является историческим этно-территориальным ареалом восточных украинцев. Территория Слобожанщины включает Харьковскую, частично Сумскую и восточные районы Полтавской области. Освоение этой территории началось с середины XVII в. преимущественнно переселенцами с Правобережья, среди которых преобладали украинские казаки (черкасы), бежавшие от шляхты крестьяне, а также значительную часть составляли русские из глубинных губерний России [25, 27, 30].

На основе данных Русской, Украинской и Белорусской антропологических экспедиций, в ходе которых был проведен единый анализ всего восточнославянского населения методами многомерной статистики, украинская популяция образует три кластера, каждый из которых подразделяется на более мелкие. Территория Слобожанщины относится ко второй географической зоне первого кластера украинской популяции и соответствует центральноукраинскому антропологическому типу, который, в свою очередь, подразделяется на западный и восточный вариант $[27,30]$. 


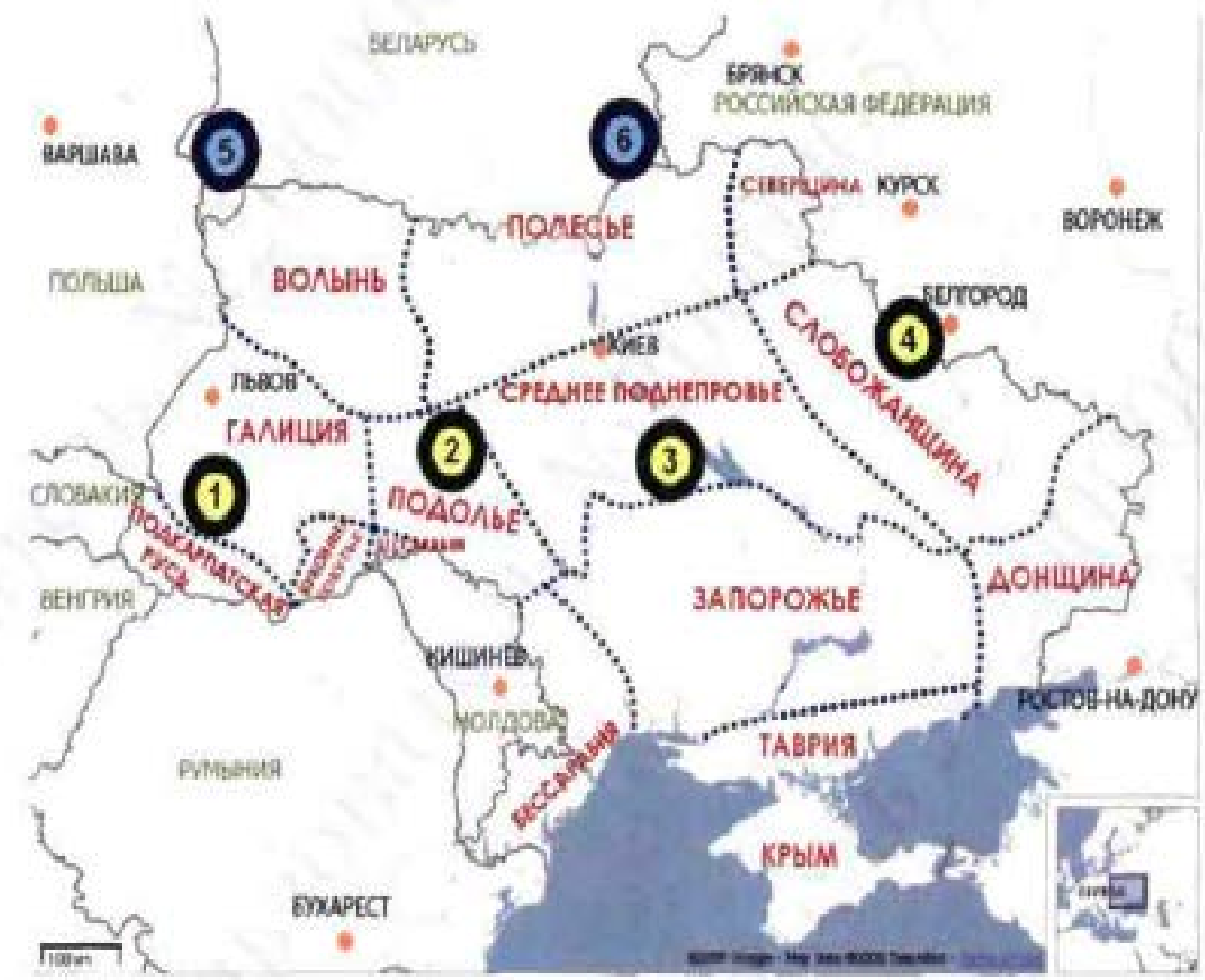

Рис. 1. Историко-этнографические территориальные подразделения украинцев в конце XIX века [Пономарев, 2000]

Обозначения, выделенные ияветными кружочками - ареальл обитания основных этнических подразделений: 1 - западные украиниьы; 2 - подольские украиниы; 3 - днепровские украиниь;; 4 - восточные украинцы; 5 -юго-западные белорусы; 6 - юго-восточные белорусы

Согласно статистическим данным на 01.01.2014 г. численность населения Слобожанщины составляет 5 млн. 328 тыс. человек (около 12,5 \% населения Украины) из них на Харьковскую область приходится 2 млн. 737 тыс. чел., Полтавскую - 1 млн. 458 тыс. чел., Сумскую - 1 млн. 133 тыс. чел. По степени моно- и полиэтничности Слобожанщина относится к смешанной зоне с преобладанием украинского населения (от 70 \% до 83 \%) и существенной долей русских (до 20 \%). Этнические меньшинства представлены армянами, азербайджанцами, белоруссами, евреями, молдаванами, цыганами. Слобожанщина является высоко урбанизированной частью Украины и наиболее промышленно и экономически развитым регионом, что формирует связанные с индустриализацией региона экологические особенности, а также высокую степень миграционных потоков [31].

Все выше перечисленные особенности Слобожанщины, вероятнее всего, будут иметь отражение в частоте распространенности и спектре НБНС, что является основой для разработки методов их ранней диагностики и предупреждения, наиболее оптимальных для региона.

\section{4. Выводы}

В заключение, необходимо отметить, что эпидемиологические и молекулярно-генетические основы большинства НБНС остаются во многом неисследованными; неясны их этиология и патогенез, но очевидно, что механизмы их формирования сложны и многообразны. И именно эти заболевания на сегодняшний день не имеет адекватных методов лечения, кроме как превентивного, т. е. направленного на предупреждение заболевания. Поэтому, для обеспечения наиболее эффективной диагностики и предупреждения НБНС необходимо изучение их распространенности, клинических и молекулярно-генетических особенностей в отдельных регионах и этнических группах.

\section{Литература}

1. Пузырев, В. П. Геномная медицина - настоящее и будущее. Молекулярно-биологические технологии в медицинской практике [Текст] / В. П. Пузырев // Новосибирск: Альфа Виста. - 2003. - Вып. 3. - С. 3-26.

2. Генетический паспорт - основа индивидуальной и предиктивной медицины [Текст] / под. ред. В. С. Баранова. СПб: Изд-во Н-Л., 2009. - 528 с. 
3. Руденская, Г. Е. Наследственные болезни ЦНС: новое в диагностике и медико-генетическом консультировании [Текст] / Г. Е. Руденская, Е. Ю. Захарова, С. В. Михайлова // Медицинская генетика. - 2008. - № 11. - С. 28-39.

4. Наследственные болезни в популяциях человека [Текст] / под ред. Е. К. Гинтер. - Москва: Медицина, 2002. $-304 \mathrm{c}$

5. Auffray, C. Systems medicine: the future of medical genomics and healthcare [Text] / C. Auffray, C. Zhu, L. Hood // Genome Medicine. - 2009. - Vol. 1, Issue 1. - P. 2.1-2.11. doi: $10.1186 / \mathrm{gm} 2$

6. Зинченко, Р. А. Особенности медико-генетического консультирования в различных популяциях и этнических группах [Текст] / Р. А. Зинченко, Е. К. // Гинтер Медицинская генетика. - 2008. - Т. 7, № 10. - С. 20-29.

7. Зинченко, Р. А. Генетическая эпидемиология наследственных болезней [Текст]: сб. матер. конф. / Р. А. Зинченко, Г. И. Ельчинова, Е. К. Гинтер // Современные достижения генетических исследований: клинические аспекты. - Ростов-на-Дону, 2004. - С. 16-24.

8. Гинтер, Е. К. Медицинская генетика [Текст] / Е. К. Гинтер. - Москва: Медицина, 2003. - 448 с.

9. Riesch, N. Categorization of humans in biomedical research: genes, race and disease [Text] / N. Riesch, E. Burchardt, E. Ziv, H. Tang // Genome Biology. - 2002. - Vol. 3, Issue 7. P. 2007.1-2007.12. doi: 10.1186/gb-2002-3-7-comment2007

10. Шишкин, С. С. Клинический полиморфизм, генетическая гетерогенность и проблемы патогенеза первичных миопатий [Текст] / С. С. Шишкин, Н. И. Шаховская, И. Н. Крахмалева // Журн. неврологии и психиатрии. 2002. - № 2. - C. 54-60.

11. Горбунова, В. Н. Введение в молекулярную диагностику и генотерапию наследственных заболеваний [Текст] / В. Н. Горбунова, В. С. Баранов. - СПб.: Спец. литература, 1997. $-287 \mathrm{c}$.

12. Иллариошкин, С. Н. ДНК-диагностика и медико-генетическое консультирование в неврологии [Текст] / С. Н. Иллариошкин, И. А. Иванова-Смоленская, Е. Д. Маркова. - М.: Мед. информ. агенство, 2002. - 591 с.

13. Руденская, Г. Е. Генетическая эпидемиология наследственных болезней нервной системы [Текст] / Г. Е. Руденская, В. С. Иноземцев, А. В. Перепелов и др. - Саранск: НИИ регионологии, 1996. - 99 с.

14. Маркова, Е. Д. Распространенность наследственных заболеваний нервной системы в различных популяциях [Текст] / Е. Д. Маркова, Р. В. Магжанов // Журн. невропатологии и психиатрии. - 1990. - № 9. - С. 113-119.

15. Лимборская, С. А. Этногеномика и этногеография народов Восточной Европы [Текст] / С. А. Лимборская, Э. К. Хуснутдинова, Е. В. Балановская. - Москва: Наука, 2002. $-264 \mathrm{c}$.

16. Зинченко, Р. А. Эпидемиология наследственных болезней в российских популяциях [Текст]: дис. ... док. мед. наук. / Р. А. Зинченко. - М., 2001. - 267 с.

17. Гинтер, Е. К. Влияние генетической структуры на груз наследственных болезней в русских популяциях [Текст] / Е. К. Гинтер // Вестник РАМН. - 1994. - № 9. C. 69-75.

18. Гинтер, Е. К. Роль факторов популяционной динамики в распространенности наследственной патологии в российских популяциях [Текст] / Е. К. Гинтер, Р. А. Зинченко, Г. И. Ельчинова, С. Д. Нурбаев // Медицинская генетика. - 2004. - Т. 3, № 12. - С. 548-555.

19. Алтухов, Ю. Л. Генетические процессы в популяциях [Текст] / Ю. Л. Алтухов. - Москва: ИКЦ «Академкнига», 2003. $-432 \mathrm{c}$.
20. Руденская, Г. Е. Генетическая эпидемиология наследственных болезней нервной системы [Текст] / Г. Е. Руденская, В. С. Иноземцева, А. В. Перепелов, А. Н. Петрин. - Саранск, 1996. - 112 с.

21. Cavali-Sforza, L. L. The genetic of human populations [Text] / Cavali-L. L. Sforza, W. F. Bodmer. - San Francisco: W. H. Freeman, 1971.

22. Зинченко Р. А. Факторы, определяющие распространение наследственных болезней в российских популяциях [Текст] / Р. А. Зинченко, Г. И. Ельчинова, Е. К. Гинтер // Медицинская генетика. - 2009. - № 8. - С. 7-23.

23. Степанов, В. А. Этногеномика населения Северной евразии $[$ Текст] / В. А. Степанов. - Томск: печатная мануфактура, 2002. - 242 с.

24. Гинтер, Е. К. Роль инбридинга и его структуры в отягощенности популяций человека наследственной патологией [Текст] / Е. К. Гинтер, А. Н. Петрин. - В кн. Профилактика наследственных болезней. М., 1987. - С. 88-102.

25. Баран, В. Д. Славяно-украинские древности. Украинцы [Текст]: монография / В. Д. Баран; под ред. Н. С. Полищук, А. П. Пономарева. - М.: Наука, 2000. - 536 с.

26. Алексеева, Т. И., Круц С.И. Древнейшее население Восточной Европы [Текст]: монография / Т. И. Алексеева, С. И. Круц; под ред. Т. И. Алексеевой. - Восточные славяне. Антропология и этническая история. - М.: Научный мир, 2002. -342 с.

27. Пономарев, А. П. Историко-этнографическое районирование [Текст]: монография / А. П. Пономарев; под ред. Н. С. Полищук, А. П. Пономарева. - Москва: Наука, 2000. $-536 \mathrm{c}$.

28. Алексеева, Т. Н., Дяченко В.Д. Антропологический облик [Текст]: монография / Т. Н. Алексеева, В. Д. Дяченко; под ред. Н. С. Полищук, А. П. Пономарева. - Украинцы. - М.: Наука, 2000. - 536 с.

29. Генофонд и геногеография народонаселения. Т. 1. Генофонд населения России и сопредельных стран [Текст] / под ред. Ю. Г. Рычкова. - СПб.: Наука, 2000. - 611 с.

30. Пономарев, А. П. Начало украинской истории [Текст]: монография / А. П. Пономарев; под ред. Н. С. Полищук, А. П. Пономарева. - Украинцы. - Москва: Наука, 2000. $-6 \mathrm{c}$

31. Государственная служба статистики Украины, 2014 г. [Электронный ресурс] / Режим доступа: http://www.ukrstat.gov.ua/

\section{References}

1. Puzyrev, V. P. (2003). Genomic Medicine - Present and Future. Molecular biological technologies in medical practice. Novosibirsk: Alpha Vista, 3, 3-26.

2. Baranov, V. S. (Ed.) (2009). The genetic passport - the basis of individual and predictive medicine. St. Petersburg: Publishing House of the H-L., 528.

3. Rudenskaya, G. E., Zakharova, E. J., Mikhailova, C. B. (2008). Hereditary diseases of the CNS: a new diagnosis and genetic counseling. Medical Genetics, 11, 28-39.

4. Ginter, E. K. (2002). Genetic diseases in human populations. Moscow: Medicine, 304.

5. Auffray, C., Chen, Z., Hood, L. (2009). Systems medicine: the future of medical genomics and healthcare. Genome Medicine, 1 (1), 2.1-2.11. doi: 10.1186/gm2

6. Zinchenko, P. A., Ginter, E. K. (2008). Features of Medical Genetics konsultirovaniya in different populations and ethnic groups. Medical Genetics, 7 (10), 20-29.

7. Zinchenko, P. A., El'chinova, G. I., Ginter, E. K. (2004). Genetic epidemiology of hereditary diseases. Proceed- 
ings of the conference "Recent advances in genetic research: clinical aspects." Rostov-on-Don, 16-24.

8. Ginter, E. K. (2003). Medical Genetics. Moscow: Medicine, 448.

9. Riesch, N., Burchardt, E., Ziv, E., Tang, H. (2002). Categorization of humans in biomedical research: genes, race and disease. Genome Biology, 3 (7), 2007.1-2007.12. doi: $10.1186 /$ gb-2002-3-7-comment2007

10. Shishkin, S., Shahovskaya, N. I., Krahmaleva, J. H. (2002). Clinical polymorphism, genetic heterogeneity and the problem of the pathogenesis of primary myopathies. Journal. neurology and psychiatry, 2, 54-60.

11. Gorbunov, V. N., Baranov, V. (1997). Introduction to molecular diagnostics and gene therapy of inherited diseases. St. Petersburg: Spec. literature, 287.

12. Illarioshkin, S. N., Ivanov-Smolensk, I. A., Markov, E. D. (2002). DNA diagnosis and medical and genetic counseling in Neurology. Moscow: Med. Inf. agency, 591.

13. Rudenskaya, G. E., Inozemtsev, V. S., Perepelovm A. V. et al. (1996). The genetic epidemiology of hereditary diseases of the nervous system. Saransk: SRI regionolo ogy, 99.

14. Markov, E. D., Magzhanov, R. V. (1990). Prevalence of hereditary diseases of the nervous system in different populations. Journal neurology and psychiatry, 9, 113-119.

15. Limborska, S. A., Khusnutdinova, E., Balanovskaya, E. V. (2002). Ethnogenomics Ethnogeography and peoples of Eastern Europe. Moscow: Nauka, 264.

16. Zinchenko, P. A. (2001). Epidemiology of hereditary diseases in the Russian populations. Moscow, 267.

17. Ginter, E. K. (1994). Effect of the genetic structure of the cargo of hereditary diseases in the Russian populations. Bulletin of Medical Sciences, 9, 69-75.

18. Ginter, E. K., Zinchenko, P. A., El'chinova, G. I., Nurbayev, S. D. (2004). The role of the factors of population dynamics in the prevalence of hereditary diseases in Russian populations. Medical Genetics, 3 (12), 548-555.
19. Altukhov, Y. L. (2003). Genetic processes in populations. Moscow: ICC “Akademkniga”, 432.

20. Rudenskaya, G. E., Inozemtseva, B. C., Perepelov, A. B., Petrin, A. N. (1996). Genetic epidemiology of hereditary diseases of the nervous system. Saransk, 112.

21. Cavali-Sforza, L. L., Bodmer, W. F. (1971). The genetic of human populations. San Francisco: W. H. Freeman.

22. Zinchenko, P. A., El'chinova, G. I., Ginter, E. K. (2009). Factors determining the spread of hereditary diseases in the Russian populations. Medical Genetics, 8, 7-23.

23. Stepanov, V. A. (2002). Ethnogenomics population of Northern Eurasia. Tomsk printing manufactory, 242.

24. Ginter, E. K., Petrin, A. N. (1987). The role of inbreeding and its structure in the family history of human populations hereditary diseases. In the book Prevention of hereditary diseases. Moscow, 88-102.

25. Baran, V. D. (2000). Slavic-Ukrainian antiquity. Ukrainians. NS Polishchuk and AP Ponomarev. Moscow: Nauka, 536.

26. Alexeev, T. I., Cruz, S. I. (2002). The oldest populap tion of Eastern Europe / Eastern Slavs. Anthropology and ethnic history. Moscow: The scientific world, with, 342.

27. Ponomarev, A. P.; Polishchuk, N. S., Ponomarev, A. P. (Eds.) (2000). Historical and ethnographic zoning. Moscow: Nauka, 536.

28. Alekseev, T. N., Dyachenko, V. D.; Polishchuk, N. S., Ponomarev, A. P. (Eds.) (2000). Anthropological look, Moscow: Nauka, 536.

29. Rychkov, Yu. G. (Ed.) (2000). The gene pool and cartography population. Volume 1 . The gene pool of the population of Russia and neighboring countries. St. Petersburg: Science, 611.

30. Ponomarev, A. P.; Polishchuk, N. S., Ponomarev, A. P. (Eds.) (2000). Beginning of Ukrainian history. Moscow: Nauka, 6.

31. State Statistics Service of Ukraine (2014). Available at: http://www.ukrstat.gov.ua/

Рекомендовано до публікаиії д-р мед. наук Корж О. М. Дата надходження рукопису 13.01.2015

Говбах Ирина Александровна, кандидат медицинских наук, доцент, кафедра общей практики-семейной медицины, Харьковская медицинская академия последипломного образования, ул. Корчагинцев, 58, м. Харків, Украина, 61000

E-mail: iragovbah@yandex.ru 